\title{
ETIOPATHOGENESIS OF PEPTIC ULCER: back to the past?
}

\author{
Mariana Barbosa ARAÚJO'1, Paulo BORINI² and Romeu Cardoso GUIMARÃES ${ }^{3}$
}

\begin{abstract}
Objective - To review some aspects of the etiopathogenesis of peptic ulcerous disease especially on the basis of studies on its correlation with Helicobacter pylori (H. pylori). Methods - A search was made in the data bases MEDLINE, LILACS and PubMed, and in Brazilian and foreign books, referring to the incidence and prevalence of infection by $H$. pylori and of peptic ulcerous disease in various populations of different countries. Results - It was observed that the prevalence of H. pylori infection is similar in individuals with peptic ulcerous disease and the general population. There are differences between countries with respect to the prevalence of infection and of gastric or duodenal peptic ulcers. In many countries the prevalence of infection by $H$. pylori shows stability while the prevalence of peptic ulcerous disease is declining. The prevalence of peptic ulcerous disease without $H$. pylori infection varies between $20 \%$ and $56 \%$ in occidental countries. Discussion - The observations might be suggestive of $H$. pylori being only one more factor to be summed together with other aggressive components in the genesis of peptic ulcerous disease. We would therewith be returning to the classic concept that peptic gastric and duodenal ulcers have multifactorial etiology and would result from imbalance between aggressive and defensive factors. The focus of studies should be enriched with the identification of the defensive factors and of other aggressive factors besides the well known $H$. pylori and non-steroidal anti-inflammatory drugs, since these two aggressors do not exhaust the full causal spectrum.
\end{abstract}

HEADINGS - Peptic ulcer. Stomach Ulcer. Duodenal ulcer. Helicobacter infections.

\section{INTRODUCTION}

Peptic ulcers are sites of loss of continuity of part of the wall of organs of the gastrointestinal tract exposed to the gastric chloridopeptic secretion. The organs affected are more frequently the stomach and the duodenum. Under some conditions it is also possible to observe peptic lesions in the esophagus and jejunum among other less common sites ${ }^{(40)}$. Lesions are chronic and single in the majority of cases but can be multiple in about $5 \%$ to $20 \%$ of cases, simultaneously affecting the stomach and the duodenum or even other segments, as occurs in the Zollinger and Ellison Syndrome ${ }^{(13,40)}$.

The etiology of the peptic ulcerous disease (PUD), gastric or duodenal, is becoming one of the most intriguing problems of gastroenterology. Up to some time before the last two decades of the past century it was considered a disease of multifactorial origin. It was assumed that it would be installed in constitutionally predisposed individuals, in consequence of disequilibrium between the action of aggressive and defensive factors upon the gastroduodenal mucosa. Duodenal ulcer would develop from the predominance of aggressive factors while gastric ulcer would result mainly from the failure of defensive factors ${ }^{(57)}$.

Some authors even hypothesized that they would be different diseases. Duodenal ulcer is usually diagnosed in younger age, typically with higher acid secretion and affecting mainly males. Gastric ulcer occurs more frequently in older patients, acid secretion is near-normal or reduced and the sex-ratio is not skewed ${ }^{(57)}$.

In Brazil, epidemiological surveys revealed that duodenal peptic ulcers are more prevalent than the gastric in a $3: 1$ proportion, besides being more prevalent in males ${ }^{(13,53)}$. In the UK, the incidence of peptic ulcer was $12 \%$ higher in men than in women ${ }^{(9)}$, although the prevalence of infection by Helicobacter pylori (H. pylori) is not associated with $\operatorname{sex}^{(50,58,64)}$.

After Marshall and Warren ${ }^{(43)}$ presented studies on the correlation between gastritis and peptic ulcer, and on the pathogenic action of $H$. pylori plus the fast evolution of knowledge on the theme, this association became established and is universally accepted. In 1994, the US National Institutes of Health recognized that $H$. pylori was directly involved 
in peptic ulcer pathogenesis ${ }^{(18)}$. On the bases of the facts that the majority of peptic ulcers were associated with the presence of $H$. pylori and that eradication of the bacteria lead to significant reduction of reinstallation of the ulcers, the microorganism became considered a decisive etiologic factor in the genesis of PUD, besides the non-steroidal antiinflammatory drugs (NSAID) ${ }^{(12)}$. Recurrence of the disease is higher in patients infected by the bacterium $(13.4 \%$ per year), relative to the patients submitted to therapy for eradication of $\mathrm{H}$. pylori $(2.5 \% \text { per year })^{(45)}$. Since then, PUD became considered either an infectious ${ }^{(26)}$ or an iatrogenic (NSAID-induced) disease; it would be a rare disease in the absence of these two factors. It became valid to affirm that in peptic ulcer the treatment of $H$. pylori means the cure of the disease ${ }^{(17)}$. More recently, to the classic aphorism "No acid no ulcer"(56) the dictum "No Helicobacter pylori no ulcer" was associated ${ }^{(10,29)}$.

This work discusses the etiopathogenesis of PUD based on a review of medical bibliography on the correlation and association between PUD and H. pylori.

\section{METHODS}

A search was made on the databases MEDLINE, LILACS and PubMed using the following keywords: "Peptic ulcerous disease or PUD", "Helicobacter pylori-negative" or "H. pylori-negative" or "Hp-negative" and "peptic ulcerous disease" or "peptic gastric ulcer" or "GUP" or "peptic duodenal ulcer" or "DUP", as well as on Brazilian and foreign books on the theme. Searches were restricted to publications in English, Portuguese or Spanish.

The searches, including the supplementations, yielded 56 original or review articles and 8 books. Some studies were discarded due to the inclusion of patients under 18 years of age, of patients in use of any NSAID (including aspirin) or with concomitant diseases that could lead to lower prevalence of infection by $\mathrm{H}$. pylori (such as atrophic gastritis, malignant ulcerous disease, cirrhosis with portal hypertension and hepatic insufficiency), as well as those bearing diseases that could cause gastric or duodenal ulcers (Crohn disease, cytomegalovirus infection, stress-related ulcer, Behcet disease). In the studies involving peptic ulcer patients, infection by $H$. pylori was diagnosed by direct demonstration of the bacteria in biopsy specimens ${ }^{(19)}$ combined with another diagnostic test, usually the Rapid Urease Test. The only exceptions to this rule were the epidemiologic studies of the infection that employed other tests (e.g., urease test on biopsies, ${ }^{13} \mathrm{C}$-urea breath test, seroprevalence of antibodies, culture and stool antigen test). Patients were classified as having $H$. pylori-negative ulcer if no test was positive and at least two tests were negative; an exception was a Brazilian study of PUD ${ }^{(42)}$, included due to the scarcity of studies in the country.

\section{RESULTS}

Infection by $H$. pylori is detected worldwide. Incidence and prevalence of the infection vary according to age of individuals and to socioeconomic conditions of each region. There is no reported difference between sexes ${ }^{(50,58)}$. Studies in different countries reveal prevalence of infection between $11 \%$ and $69 \%$ in the general population ${ }^{(7)}$ and between $8.9 \%$ and $72.8 \%$ in children, respectively in developed and developing countries ${ }^{(42)}$. Along recent years a reduction of the infection rates was observed, most evident in occidental industrialized countries and in some oriental emergent economies $^{(5,6,7)}$. Various studies indicate that the incidence and prevalence of colonization by $H$. pylori have declined progressively with industrialization in different countries ${ }^{(4,34)}$. While the prevalence of infection is higher in underdeveloped and developing countries, there is also a reduction of the infection in them, attributed to the eradication therapy and to the improvement of sanitary conditions observed in the last two decades ${ }^{(7)}$.

Brazilian studies on the prevalence of infection by H. pylori were conducted in limited population samples of some states. It was found high, from 59.5\% in Rio de Janeiro (RJ) to $96 \%$ in São Luis (MA) ${ }^{(35)}$. High prevalence was also reported in a low income community of Fortaleza (CE): $73.3 \%$ in the age range from 11 to 20 years and above $87 \%$ at 60 years of age or more ${ }^{(52)}$. In the city of São Paulo, prevalence of infection was below $65.6 \%$ in the population of high income ${ }^{(50)}$; among blood donors the infection was of $66.5 \%$ of 746 males and of $63.2 \%$ in 247 females $^{(64)}$. An overall decline in prevalence of $H$. pylori was noted in both high and low socioeconomic status countries ${ }^{(7)}$.

The duodenum is the major location of peptic ulcers in the western population; the gastric location is more frequent in oriental countries, particularly Japan ${ }^{(46)}$. The relevance of H. pylori for the genesis of the mucosal ulceration is well supported by the identification of the bacterium in $90 \%-95 \%$ of duodenal ulcer patients and $60 \%-80 \%$ of patients with gastric ulcer, as compared to $25 \%-30 \%$ in symptomatic controls ${ }^{(46)}$. In developing countries, all studies up to now are consistent in detecting the bacterium in over $90 \%$ of bearers of peptic ulcers $^{(17)}$. Otherwise, the decline in the incidence of PUD cannot be explained by population or demographic changes ${ }^{(9)}$ while the increase in the frequency of non- $H$. pylori ulcers cannot be explained solely by the declining rates of infection $^{(23)}$. In Brazil, the prevalence of duodenal ulcer decreased from $8.6 \%$ in 1996 to $3.3 \%$ in $2005^{(54)}$.

The review of Blaser ${ }^{(5)}$ showed that the rate of PUD, especially at the duodenum, was increasing in the USA and in Europe during the last decade, while there was evidence that the rate of $H$. pylori colonization was declining for a long time. Another review of Sung et al. ${ }^{(61)}$ encompassing various countries reported reduction of both the rates of 
PUD and of the proportion of ulcerous patients infected by the bacterium, especially in occidental countries. A variety of studies referring to diverse world regions have been pointing to an increase throughout recent time of the prevalence of $H$. pylori-negative duodenal ulcer or idiopathic peptic ulcer $^{(8,16,29,31-33,37,38,47,51,55,59,63)}$ (Table 1). A meta-analysis of seven double blind, randomized trials in North America found that $20 \%$ of patients with $H$. pylori-associated ulcers had ulcer recurrence within 6 months despite successful $H$. pylori eradication and no reported NSAID use ${ }^{(37-39)}$.

No role could be proposed for the smoking habit on the basis of two studies, either on non- $H$. pylori and non-NSAID duodenal ulcers or on $H$. pylori-associated ulcers ${ }^{(49,63)}$.

In developed countries there was wide variation in the rates of DUP and of infection by H. pylori. In Scotland the prevalence of infection was $65 \%$, and $95 \%$ of the ulcers were associated with infection ${ }^{(45)}$. Results from the USA suggest that the proportion of $H$. pylori-negative ulcer, while varying somewhat, appears to be rising ${ }^{(60)}$; the prevalence of infection in some regions may be of only $30 \%$, and about $20 \%$ of the PUD patients are not infected ${ }^{(45)}$. Quan and Talley ${ }^{(49)}$ systematically reviewed the prevalence of unexplained ulceration in the period between 1995 and 2001, finding that a relevant proportion of PUD patients were not infected by $\mathrm{H}$. pylori. Other studies in the USA showed that $20 \%$ to $50 \%$ of the peptic ulcers were not related to $H$. pylori infection or to the use of NSAID ${ }^{(14,15,23,25)}$. In studies published along the last ten years, totaling 16,080 patients, the average prevalence of $\mathrm{H}$. pylori infection in duodenal peptic ulcer was of $81 \%$; the rate declined to $77 \%$ when only the last five years of the sample were considered ${ }^{(25)}$. In New York, among non-users of NSAID, only $61 \%$ of peptic ulcer patients presented the H. pylori infection (conversely, 39\% of PUD patients were $H$. pylori-negative); among 2,900 patients bearers of duodenal ulcer, $27 \%$ did not report usage of NSAID and were $H$. pylori-negative ${ }^{(14)}$.

In the USA the hospitalization rate due to PUD experienced an average reduction of 21\% between 1998 and 2005, more pronounced among women with gastric ulcer. Among hospitalized individuals, $47 \%$ did not present $H$. pylori infection. Higher rates of $H$. pylori-negative PUD patients were found at ages equal or above 65 years $(54 \%)$ and among white skin color $(56 \%)^{(22)}$

The incidence of not further complicated PUD in the UK decreased to little more than half between the years 1997 and 2005 , the reduction of duodenal ulcer being greater than that of gastric ulcer. The number of confirmed $H$. pylori-negative cases increased from $5 \%$ to $12 \%$ from the first to the last year in the study ${ }^{(9)}$.

In Japan and Hong Kong, the rates of PUD not associated with usage of NSAID or with $H$. pylori infection were of only $1.3 \%$ and $4.1 \%$, respectively ${ }^{(15,30)}$. Both of these studies highlighted that the proportions of idiopathic PUD were increasing. In Korea, the prevalence of $H$. pylori infec-

TABLE 1. Prevalence of Helicobacter pylori-negative peptic ulcer among non-NSAID users

\begin{tabular}{|c|c|c|c|c|c|}
\hline Reference (Country) & $\begin{array}{c}\text { Year of } \\
\text { publication }\end{array}$ & $\begin{array}{l}\text { Method of } H \text {. pylori } \\
\text { detection }\end{array}$ & $\begin{array}{c}\text { Number } \\
\text { of patients }\end{array}$ & Ulcer type & $\begin{array}{l}\% \text { non-NSAID } \\
\text { H. pylori-negative }\end{array}$ \\
\hline McColl et al. ${ }^{(44)}$ (Scotland) & 1993 & Histology and CLO test & 12 & DU & 50 \\
\hline Graham et al. ${ }^{(26)}$ (USA) & 1995 & Histology and CLO test & 139 & DU & 33 \\
\hline \multirow{2}{*}{ Bakkevold $^{(3)}$ (Norway) } & \multirow{2}{*}{$1995-1996$} & \multirow{2}{*}{ Histology and CLO test } & 62 & DU & 18 \\
\hline & & & 25 & GU & 12 \\
\hline Lanza et al. ${ }^{(38)}$ (USA) & 1996 & Histology and CLO test & 183 & DU & 30 \\
\hline Peterson et al. ${ }^{(47)}$ (USA) & 1996 & Histology and CLO test & 128 & DU & 27 \\
\hline Sprung et al. ${ }^{(60)}$ (USA) & 1997 & Histology and CLO test & 59 & DU & 52 \\
\hline Kemppainem et al. ${ }^{(32)}$ (Finland) & 1997 & Histology and CLO test & 125 & PUD & 30 \\
\hline \multirow{2}{*}{ Jyotheeswaran et al. $^{(31)}$ (USA) } & \multirow{2}{*}{1998} & \multirow{2}{*}{ Histology and CLO test } & 160 & DU & 39 \\
\hline & & & 145 & GU & 39 \\
\hline Laine et al. ${ }^{\left({ }^{37)}\right.}$ (USA) & 1998 & Histology and CLO test & 619 & DU & 20 \\
\hline \multirow{2}{*}{ Schubert et al. ${ }^{(55)}$ (USA) } & \multirow{2}{*}{1999} & \multirow{2}{*}{ Histology and CLO test } & 41 & DU & 39 \\
\hline & & & 43 & GU & 47 \\
\hline Ciocola et al. ${ }^{(16)}$ (USA) & 1999 & Histology and CLO test & 2394 & DU & 27 \\
\hline \multirow{2}{*}{ Xia et al. ${ }^{(63)}$ (Australia) } & \multirow{2}{*}{1999} & \multirow{2}{*}{ Histology and CLO test } & 14 & DU & 43 \\
\hline & & & 33 & GU & 58 \\
\hline Bytzer et al. ${ }^{(8)}$ (Denmark) & 2001 & Histology and CLO test & 276 & DU & 19 \\
\hline \multirow{2}{*}{ Bakkevold $^{(3)}$ (Norway) } & \multirow{2}{*}{$2007-2008$} & \multirow{2}{*}{ Histology and CLO test } & 47 & DU & 43 \\
\hline & & & 28 & GU & 57 \\
\hline \multirow{2}{*}{ Feinstein et al. ${ }^{(22)}$ (USA) } & \multirow{2}{*}{2010} & \multirow{2}{*}{ Histology and CLO test } & 770 & DU & 50 \\
\hline & & & 548 & GU & 40 \\
\hline \multirow{2}{*}{ Marques et al. ${ }^{(42)}$ (Brazil) } & \multirow{2}{*}{2011} & \multirow{2}{*}{ CLO test } & 391 & DU & 36 \\
\hline & & & 103 & GU & 43 \\
\hline
\end{tabular}

NSAID: non-steroidal anti-inflammatory drug; CLO: rapid urease test; DU: duodenal ulcer; GU: gastric ulcer; PUD: peptic ulcer disease, location unspecified 
tion in association with gastric ulcer was increasing in more recent years, whereas $H$. pylori infection in duodenal ulcer was decreasing ${ }^{(30)}$.

The prevalence of PUD has not been adequately evaluated in Brazil, while the prevalence of $H$. pylori infection is high. A report on patients in the southern states revealed low prevalence of duodenal peptic ulcer ${ }^{(54)}$. Marques et al. ${ }^{(42)}$ studied 1478 consecutive higher digestive organ endoscopic examinations realized in a tertiary care hospital in the city of São Paulo, finding peptic ulcers in 494 (33.4\%). Infection with $H$. pylori was diagnosed in $252(64 \%)$ patients with duodenal ulcer, $59(57 \%)$ of bearers of gastric ulcer and $143(53 \%)$ patients with normal endoscopy. The rates of $H$. pylori-negative patients were moderately high, $36 \%$ of the duodenal and $43 \%$ of the gastric ulcerous.

\section{DISCUSSION}

It seems significant that, more recently, there has been an accumulation of medical studies coming from different regions indicating that an appreciable proportion of gastric and duodenal peptic ulcers is not related to $H$. pylori infection or to the use of NSAID. An appraisal of the data compiled above indicates that about $20 \%$ to $56 \%$ of PUD did not find a defined etiology, being included in the idiopathic PUD category.

The review of Blaser ${ }^{(5)}$ showed that the rate of PUD, especially of duodenal localization, started an increasing trend in the USA and Europe, while there was evidence that the rate of $H$. pylori colonization was starting to fall. In industrialized countries, after a peak in the early decades of the last century, the incidence of PUD and the prevalence $H$. pylori colonization started a declining trend. It has been questioned why the occurrence of PUD is increasing at the same time when the prevalence of $\mathrm{H}$. pylori infection declines ${ }^{(6)}$.

It has been observed that the prevalence of PUD did not change in concomitance with the regimes of $H$. pylori eradication in the countries with low prevalence of the infection ${ }^{(6)}$. The increase in the rate of eradication of the bacterium in the USA did not result in reduction of the rates of hospital admissions related to complications from PUD ${ }^{(41)}$.

Varied argumentation has been presented attempting to justify the occurrence of PUD in the absence of $\mathrm{H}$. pylori infection but we consider that the great majority, if not the totality of the justifications do not resist criticisms.

Patients without present evidence of colonization by $H$. pylori would have had a previous infection responsible for permanent alterations in the gastro-duodenal mucosa that facilitated development of the PUD ${ }^{(45)}$.

It remains controversial whether gastric mucosal atrophy and duodenal metaplasia are reversible or not after eradication of the infection ${ }^{(62)}$. Furthermore, such possible mucosal alterations are difficult to confirm in consequence of not being possible, in the majority of cases, to obtain data on the previous conditions with respect to the presence of $H$. pylori in the population included in the studies ${ }^{(20,62)}$. Anatomopathological studies on peptic ulcers refer signs of inflammation in the regions surrounding the ulcer but not signs of mucosal atrophy ${ }^{(62)}$. About $30 \%$ of patients with idiopathic ulcers show histological characteristics suggestive of previous infection, indicating that eradication of the infection does not protect against recurrence of the peptic ulcer ${ }^{(15)}$. About $20 \%$ or more of the cured of $H$. pylori infection may develop subsequent $H$. pylori-negative ulcer ${ }^{(36)}$.

Elevation of gastric $\mathrm{pH}$ in consequence of the utilization of some antibiotics, high doses of $\mathrm{H}_{2}$ antagonists or of proton pump inhibitors would strongly reduce urease activity, therewith leading to false-negative results with respect to $H$. pylori infection through the urease or respiratory tests ${ }^{(1,28,36)}$. Furthermore, these medications reduce bacterial density in the organ ${ }^{(27)}$.

Gastric alkalinization and the use of some antibiotics could be causes of false-negative urease or respiratory tests. Otherwise, these queries might not apply to the studies reviewed here, which were all based on histologic search for the bacteria in biopsy materials.

The rise in the number of idiopathic peptic ulcers has been attributed to diagnostic errors. Gisbert et al. ${ }^{(24)}$ observed that the rate of diagnostic sensitivity from biopsies with urease test and histological examination was of $83 \%$ in analyses of samples from corpus and antrum concomitantly, decreasing to $78 \%$ with material collected from only one of the regions. In order to be sure of the absence of the infectious cause of the peptic ulcer, it is also recommended that samples should be examined from both antrum and corpus, and utilizing two different tests, with negative results for both ${ }^{(62)}$. A lower bacterial density in the antrum can lead to false-negative urea respiratory tests ${ }^{(1,20,28,36)}$.

It is general to endoscopic procedures that samples be taken from both antrum, where the majority of the ulcers reside, and corpus, where bacterial populations are higher. It is also general knowledge of specialists that in biopsies of areas immediately adjacent to peptic ulcers the finding of bacteria is not highly probable, the results being negative even in cases with intense colonization density. If these facts are assumed well known to endoscopists it should be wise to accept that the biopsies are good representatives of reality, being also improbable that the pathologists would have recently lost the ability to identify the bacteria. Examination of the biopsy fragments through the usual Giemsa staining allows demonstration of the bacteria in $80 \%$ to $97 \%$ of cases $^{(21)}$.

The diagnosis of infection by $H$. pylori is impaired in cases of peptic ulcers with acute complications (bleeding, obstruction, perforation $)^{(11,24)}$

Studies compiled in this review did not include patients with obstruction or perforation installed upon PUD. In all patients with acute bleeding, the search for H. pylori was conducted in gastric biopsies obtained after the bleeding was controlled, with repetition of the procedure whenever necessary. It is also not likely that false-negative results would occur repetitively, especially after the complication is circumvented. In such circumstances, Bakkevold ${ }^{(3)}$ repeated the gastric biopsy and found that, when the bacteria are present, both histopathological and rapid urease tests were positive for diagnosis of the infection. 
Gastric biopsies might not reveal the presence of bacteria in cases where the colonization and the ulcerous disease are restricted to the duodenum ${ }^{(48)}$.

The study of Pietroiusti et al. ${ }^{(48)}$ refers to 608 PUD patients of which $6,9 \%$ (42 patients) did not present gastric infection. Among the latter, $H$. pylori was not detected in the duodenum in $24(57 \%)$, whereas 18 patients had a positive duodenal culture for Helicobacter that is $2.9 \%$ from the total sample. The authors informed that duodenal colonization by species of Helicobacter other than $H$. pylori cannot be excluded since the cagA-negative genotype was higher in patients with isolated duodenal colonization, when compared with patients presenting the usual pattern of colonization. While there are no explanations for the exclusive duodenal location, its prevalence is so scanty that would not justify the rise of $H$. pylori-negative PUD.

The finding of $H$. pylori-negative cases could derive from the extensive use of antibiotics starting from the last decades of the past century. Such usage could contribute in a short term basis to negative results in bacterial detection tests ${ }^{(21,24,61)}$.

This possibility might be relevant but with some pondering. The large majority of antibiotics do not affect specifically $H$. pylori. In case a temporary eradication is obtained, clinical symptoms should also disappear from the temporary cure of the disease and consequently the patients would not have the need for looking after medical assistance and would not be submitted to the endoscopic examination. Even when this examination is conducted at least the scar of the lesion should be observed.

\section{CONCLUSION}

The prevalence of $H$. pylori infection is similar in individuals with PUD and in the general population. Since the incidence and prevalence of the infection by the bacteria is similar in males and females, other factors should be advocated to explain the reasons for the higher prevalence of duodenal PUD in males and for the finding in some countries, including Brazil, of the 3:1 ratio of prevalence between duodenal and gastric ulcers. There are differences between countries with respect to the prevalence of infection and of gastric and duodenal peptic ulcers. In various countries, the prevalence of infection is stable while that of PUD is decreasing. Occurrence of $H$. pylori-negative PUD is being detected in significant proportions and these are higher than would be expected according to the etiologic conception of being an infectious disease.

These considerations might be taken in support of the conception that $H$. pylori would be only one more of the strong aggressive factors known to cause peptic ulcers, aside with the NSAID. Under this panorama, we would be turning back to the concept that peptic gastric and duodenal ulcers have a multifactorial etiology and result, as it was assumed in the past, from disequilibrium between aggressive and defensive factors acting in the mucosa. A consequence of the recognition of this conception would be the reinforcement of the focus on the search for the possible other factors.

At present there is little doubt that eradication of $H$. pylori is mandatory to ensure successful treatment of gastric and duodenal ulceration ${ }^{(46)}$. The 1994 National Institutes of Health Consensus Conference concluded that ulcer disease was an infectious disease that could be cured by bacterial eradication ${ }^{(2)}$. However, the more recent reports suggesting that a considerable proportion of peptic ulcer may be non-infectious in origin would indicate a change in the management strategies since non-infectious ulcer cannot be cured with antibiotics. A call for concern would spring from the report of Bytzer et al. ${ }^{(8)}$ indicating that H. pylori-negative duodenal ulcers were associated with a poorer prognosis mainly because of a higher rate of ulcer and symptom relapse.

Araujo MB, Borini P, Guimarães RC. Etiopatogenia da úlcera péptica: de volta ao passado? Arq Gastroenterol. 2014,51(2):155-61.

RESUMO - Objetivo - Revisar a etiopatogenia da doença ulcerosa péptica com base em revisão de estudos sobre a correlação entre Helicobacter pylori (H. pylori) e doença ulcerosa péptica. Métodos - Foi realizada busca nas bases de dados MEDLINE, LILACS e PubMed, e em livros brasileiros e estrangeiros referentes à incidência e prevalência de infecção pelo H. pylori e de doença ulcerosa péptica em várias populações de diferentes países. Resultados - Observamos que a prevalência da infecção pelo $H$. pylori é semelhante em indivíduos com doença ulcerosa péptica e a população geral; que existem diferenças entre países no que tange as prevalências de infecção e a de úlceras péptica gástrica e duodenal e que, em muitos países, a prevalência de infecção pelo $H$. pylori se mantém estável, enquanto a prevalência de doença ulcerosa péptica está em queda. A prevalência de doença ulcerosa péptica na ausência de infecção pelo $H$. pylori varia de $20 \%$ a $56 \%$ nos países ocidentais. Discussão - As observações sugerem que o $H$. pylori constituiria somente mais um fator a ser somado ao rol dos agressores na gênese da doença ulcerosa péptica. Assim, estaríamos retornando ao conceito de que as úlceras pépticas, gástrica e duodenal, têm etiologia multifatorial e decorreriam, como era admitido no passado, do desequilíbrio entre fatores agressivos e defensivos da mucosa. $\mathrm{O}$ foco dos estudos deveria ser redirecionado à identificação dos fatores defensivos e de outros fatores agressivos além dos bem conhecidos H. pylori e medicamentos anti-inflamatórios não-esteróides, desde que esses dois agentes não cobrem todo o espectro de causas.

DESCRITORES - Úlcera péptica. Úlcera gástrica. Úlcera duodenal. Infecções por Helicobacter. 


\section{REFERENCES}

1. Adachi K, Fujishiro H, Mihara T, Komazawa Y, Kinoshita Y. Influence of lansoprazole, famotidine, roxatidine and rebamipide administration on the urea breath test for the diagnosis of Helicobacter pylori infection. J Gastroenterol Hepatol. 2003;18:168-71

2. Anonymous. Helicobacter pylori in peptic ulcer disease. JAMA. 1994;272:65-9.

3. Bakkevold KE. Time trends in incidence of peptic ulcer bleeding and associated risk factors in Norway 1985-2008. Clin Exp Gastroenterol. 2010;3:71-7.

4. Banatvala N, Mayo K, Megraud F, Jennings R, Deeks JJ, Feldman RA. The cohort effect and Helicobacter pylori. J Infect Dis. 1993;168:219-21.

5. Blaser MJ. Helicobacters are indigenous to the human stomach: duodenal ulceration is due to changes in gastric microecology in the modern era. Gut. 1998;43:721-7

6. Blaser MJ. Hypothesis: the changing relationships of Helicobacter pylori and humans: implications for health and disease. JID. 1999;179:1523-30.

7. Bruce MG, Maaroos HI. Epidemiology of Helicobacter pylori infection. Helicobacter. 2008;13(Suppl. 1):1-6.

8. Bytzer P, Teglbjaerg PS, Danish Ulcer Study Group. Helicobacter pylori-negative duodenal ulcer: prevalence, clinical characteristics, and prognosis - results from a randomized trial with 2 -year follow-up. Am J Gastroenterol. 2001;96:1409-16.

9. Cai S, Rodríguez LAG, Massó-González EL, Hernández-Díaz S. Uncomplicated peptic ulcer in the UK: trends from 1997 to 2005. Aliment Pharmacol Ther 2009;30:1039-48

10. Castro LP, Coelho LGV. Helicobacter pylori: importância e tratamento. In Clínica Médica Contemporânea II, Lopes AC, Cardoso Filho MC (eds). São Paulo: Sarvier. 1995. p.415-6.

11. Chan HL, Wu JC, Chan FK, Choi CL, Ching JY, Lee YT, et al. Is non Helicobacter pylori, non NSAID peptic ulcer a common cause of upper GI bleeding? A prospective study of 977 patients. Gastrointest Endosc. 2001;53:438-42.

12. Chehter L. Úlcera péptica gastroduodenal (não complicada). In: Manual de Gastroenterologia. Forones NM, Miszputen SJ (coordenadores). São Paulo: EPM - Editora de Projetos Médicos. 2000. p. 26-36

13. Chinzon D, Eisig JN, Cury M, Zaterka S. Úlcera péptica. In: Coelho JCU, editor. Aparelho digestivo: clínica e cirurgia. São Paulo: Ateneu. 2006; p. 522-43.

14. Chow DKL, Sung JJY. Is the prevalence of idiopathic ulcers really on the increase? Nature Clinical Practice. 2007;4:176-7.

15. Chow DKL, Sung JJY. Non NSAID non $H$. pylori ulcer disease. Best Pract Res Clin Gastroenterol. 2009;23:3-9.

16. Ciociola AA, McSorley DJ, Turner K, Syke D, Palmer JB. Helicobacter pylori infection rates in duodenal ulcer patients in the United State may be lower than previously estimated. Am J Gastroenterol. 1999;94:1834-40.

17. Coelho LGV, Castro LP. Helicobacter pylori - desafios para a sua erradicação em países desenvolvidos. In: Terapêutica em Gastroenterologia - Temas de Atualização do Curso pré congresso; Congresso Brasileiro de Gastroenterologia. Rosa H, Dani R, Alves JG (eds). São Paulo: Lemos Editorial. 2002. p. 51-9.

18. Coelho LGV. Helicobacter pylori e doenças gastroduodenais. In: Gastroenterologia \& Hepatologia - Diagnóstico e tratamento. Mincis M (ed). São Paulo: Lemos-Editorial. 1997. p. 313-32.

19. Cutler AF. Testing for Helicobacter pylori in clinical practice. Am J Med. 1996;100:355-9 S.

20. Desai JC, Goo T, Fukata M, Sanyal S, Dikman A, Miller K, et al. NSAID-induced antral ulcers are associated with distinct changes in mucosal gene expression. Aliment Pharmacol Ther. 2009;30:71-81.

21. El-Zimaity HM, Graham DY, Al-Assi MT, Malaty H, Kartunnen TJ, Graham DP, et al. Interobserver variation in the histopathological assesment of Helicobacter pylori gastritis. Hum Pathol. 1996;27:35-41.

22. Feinstein LB, Holman RC, Christensen KLY, Steiner CA, Swerdlow DL. Trends in hospitalizations for peptic ulcer disease, United States, 1998-2005. Research. 2010;16:1410-8.

23. Freston SW. Review article: role of proton pump in non-H. pylori-related ulcers. Aliment Pharmacol Ther. 2001;15(Suppl. 2):2-5.

24. Gisbert JP, Abraira V. Accuracy of Helicobacter pylori diagnostic tests in patient with bleeding peptic ulcer: a systematic review and meta-analysis. Am J Gastroenterol. 2006;101:848-63.

25. Gisbert JP, Calvet X. Helicobacter pylori-negative duodenal ulcer disease. Aliment Pharmacol Ther. 2009;30:791-815.

26. Graham D. Foreword. In: Lee A, Mégraud F, editors. Helicobacter pylori: techniques for clinical diagnosis \& basic research. London: Saunders; 1996.

27. Graham DY, Genta R, Evans D, Reddy R, Clarridge JE, Olson CA, et al. Helicobacter pylori does not migrate from the antrum to the corpus in response to omeprazole. Am J Gastroenterol. 1996, 91:2120-4.

28. Graham DY, Opekun AR, Hammoud F, Yamaoka Y, Reddy R, Osato MS, et al. Studies regarding the mechanism of false negative urea breath tests with proton pump inhibitors. Am J Gastroenterol. 2003;98:1005-9.
29. Graham DY. Campylobacter pylori and peptic ulcer disease. Gastroenterology. 1989;96:615- 25 .

30. Jang HJ, Choi MH, Shin WG, KimKH, Chung YW, Kim KO, et al. Has peptic ulcer disease changed during the past ten years in Korea? A prospective multi-center study. Dig Dis Sci. 2008;53:1527-31.

31. Jyotheeswaran S, Shah N, Jin HO, Potter GD, Ona FV, et al. Prevalence of Helicobacter pylori in peptic ulcer patients in greater Rochester, NY: is empirical triple therapy justified? Am J Gastroenterol. 1998;93:574-8.

32. Kemppainem H, Raiha I, Sourander L. Clinical presentation of ulcer peptic in the elderly. Gerontology. 1997;43:283-8.

33. Konturek SJ, Bielanski W, Plonka M, Pawlik T, Pepera J, Konturek PC, et al. Helicobacter pylori, non-steroidal anti-inflammatory drugs and smoking in risk pattern of gastroduodenal ulcers. Scand J Gastroenterol. 2003;38:923-30.

34. Kosunen TU, Aromaa A, Knekt P, Salomaa A, Rautelin H, Lohi P, et al. Helico bacter antibodies in 1973 and 1974 in the adult population of Vammala, Finland. Epidemiol Infect. 1997;119:29-34

35. Ladeira MSP, Salvadori DMF, Rodrigues MAM. Biopatologia do Helicobacter pylori. J Bras Patol Med Lab. 2003;39:335-42.

36. Laine L, Estrada R, Trujillo M, Knigge K, Fennerty MB. Effect of proton pump inhibitors therapy on diagnostic testing for Helicobacter pylori. Ann Intern Med. 1998;129:547-50.

37. Laine L, Hopkins RJ, Girardi LS. Has the impact of Helicobacter pylori therapy on ulcer recurrence in the United States been overstated? A meta-analysis of rigorously designed trials. Am J Gastroenterol. 1998;93:1409-15.

38. Lanza F, Ciociola AA, Sykes DL, Sontag SJ, Heath A, McSortey DJ. Ranitidine bismuth citrate plus Claritomicin is effective in eradicating $H$. pylori, healing duodenal ulcer, and preventing ulcer relapse. Gastroenterology. 1996;110:A172.

39. Lanza F, Goff J, Silvers D, Winters J, Jhala N, Jennings D, et al. Prevention of duodenal ulcer recurrence with $15 \mathrm{mg}$ lanzoprazole: a double-blind placebo-controlled study. The Lansoprazole Study Group. Dig Dis Sci. 1997;42:2529-36.

40. Liu C, Crawford JM. O trato gastrointestinal. Robbins e Cotran: patologia bases patológicas das doenças. In: Kumar V, Abbas A, Fausto N, editores. Rio de Janeiro: Elsevier. 2005. p. 837-918.

41. Manuel D, Cuttler A, Goldstein J, Fennerthy MB, Brown K. Decreasing prevalence combined with increasing eradication of Helicobacter pylori in the United States has not resulted in fewer hospital admissions for peptic ulcer disease-related complications. Aliment Pharmacol Ther. 2007;25:1423-7.

42. Marques SB, Mattar R, Artifon ELA, Sakai P, Carrilho FJ. High prevalence of duodenal ulcer in a tertiary care hospital in the city of São Paulo, SP, Brazil. Arq Gastroenterol. 2011;48:171-4.

43. Marshall BJ, Warren JR. Unidentified curved bacilli in the stomach of patients with gastritis and ulcer disease. Lancet. 1984;1:1311-5.

44. McColl K, El-Nujumi AM, Chittajallu RS, Dahill SW, Dorrian CA, E-Omar E, et al. A study of the pathogenesis of Helicobacter pylori-negative chronic duodenal ulceration. Gut. 1993;34:762-8.

45. McColl KEL. Helicobacter pylori-negative nonsteroidal anti-inflamatory drug negative ulcer. Gastroenterol Clin North Am. 2009;38:353-61.

46. Modlin IM, Sachs G-Gastric and duodenal ulcer disease. In: Modlin IM, Sachs G eds. Acid related diseases - biology and treatment. Konstanz: Druckerei Konstanz GmbH. 1998. p. 199-236.

47. Peterson WL, Ciociola AA, Sykes DL, McSorley DJ, Webb DD. Ranitidine bismuth citrate plus claritrommicin is effective for healing duodenal ulcers, eradicating $H$. pylori and reducing ulcer recurrence. Gastroenterology. 1996;110:A172.

48. Pietroiusti A, Forlini A, Magrini A, Galante A, Bergamaschi A. Isolated $H$. $p y-$ lori duodenal colonization and idiopathic duodenal ulcers. Am J Gastroenterol. 2008;103:55-61.

49. Quan C, Talley NJ. Management of peptic ulcer disease not related to Helicobacter pylori or NSAIDS. Am J Gastroenterol. 2002;97:2950-61.

50. Queiroz DMM, Luzza F. Epidemiology of Helicobacter pylori infection. Helicobacter. 2006;11:1-5.

51. Ramirez-Ramos A, Chinga Alayo E, Mendoza Requena D, Leey Casela J, Segovia Castro MC, Otoya C. Changes in the prevalence of $H$. pylori in Peru; during the 1985-2002 period in medium and upper socio-economic strata. Rev Gastroentero Peru. 2003;23:92-8.

52. Rodrigues MN, Queiroz DMM, Rodrigues RT, Rocha AMC, Luz CRL, Braga LLBC. Prevalência da infecção pelo Helicobacter pylori em Fortaleza, Ceará. Rev. Saúde Pública, 2005;39:847-9.

53. Romero JMC, Rodríguez EML. Tratamiento de la úlcera péptica. Medifam. 2002; $12: 314-8$

54. Saul C, Teixeira CR, Pereira-Lima JC, Torresini RJS. Redução da prevalência de úlcera duodenal: um estudo brasileiro (análise retrospectiva na última década: 1996-2005) .Arq Gastroenterol. 2007;44:320-6.

55. Schuber M, DeWitt JM, Taylor CA. Prospective evaluation of the prevalence of H.pylori in duodenal and gastric ulcer: is its role overstated? Gastroenterology 1999;16:A305. 
56. Schwartz K. Über penetrierende magen und jejunal geschwure. Beiträge zur klinische Chirurgie. 1910;67:95

57. Shay H, Sun DCH. Etiologia y anatomia patológica de la úlcera gástrica y duodenal. In: Bockus HL. Gastroenterologia. Barcelona: Salvat. 1971. p. 443-90.

58. Shi R, Xu S, Zang H, Ding Y, Sun G, Huang X, et al. Prevalence and risk factors for Helicobacter pylori infection in Chinese populations. Helicobacter. 2008;13:157-65.

59. Sprung DJ, Apter MN, Allen B. The prevalence of Helicobacter pylori in duodenal ulcer disease - a community based study. Am J Gastroenterol. 1996;91:1926.

60. Sprung DJ, Gano B. The natural history of duodenal ulcer disease and how it relates to $H$. pylori - a community study. Am J Gastroenterol. 1997;92:1655-A 286
61. Sung JJY, Kuipers EJ, El-Serag HB. Systematic review: the global incidence and prevalence of peptic ulcer disease. Aliment Pharmacol Ther. 2009;29:938-46.

62. Toyokawa T, Suwaki K, Miyake Y, Nakatsu M, Ando M. Eradication of Helicobacter pylori infection improved gastric mucosal atrophy and prevented progression of intestinal metaplasia, especially in the elderly population: a long-term prospective cohort study. J Gastroenterol Hepatol. 2010;25:544-7.

63. Xia H, Phung N, Kalantar J, Talley NJ. Characteristics of Helicobacter pylori positive and negative peptic ulcer disease. Gastroenterology. 1999;116:A359.

64. Zaterka S, Eisig JN, Chinzon D, Rothstein W. Factors related to Helicobacter pylori prevalence in an adult population in Brazil. Helicobacter. 2007;12:82-8.

Received 26/8/2013

Accepted 19/12/2013. 